\title{
A TRANSFORMAÇÃO DO ESPAÇO RURAL MOÇAMBICANO RUMO À SOCIALIZAÇÃO DO CAMPO
}

\author{
THE TRANSFORMATION OF MOZAMBIQUE RURAL AREA \\ TOWARDS THE FIELD OF SOCIALIZATION
}

\section{LA TRANSFORMATION DE LA ZONE RURALE MOZAMBICAIN VERS LA SOCIALISATION DE CHAMP}

\section{Elmer Agostinho Carlos de Matos}

Professor de Geografia na Universidade Eduardo Mondlane, em Moçambique. Doutorando em Geografia na Universidade Federal do Rio Grande do Sul (UFRGS).Av. Juca Batista, 1200, casa 43, Porto Alegre/RS.05199728205 E.mail:elmermats@yahoo.com.br

\section{Rosa Maria Vieira Medeiros}

Doutorado em Geografia pela Université de Poitierse Pós-doutorado no GREGUM - Université du Maine - França (2008). Docente na Universidade Federal do Rio Grande do Sul. Rua Soldado José da Silva, 526, casa 6, Bairro Agronomia, Porto Alegre/RS.05182895481.E.mail:rmvmedeiros@yahoo.com.br

\section{RESUMO}

O rural moçambicano passou por transformações na forma de organização do espaço residencial e produtivo em função dos interesses do Estado, quer seja ele colonial como o que surgiu da luta de libertação nacional. Comeste artigo pretendemos analisar como o domínio dos sistemas de objetos e de ações no espaço foi fundamental para a materialização dos interesses dos atores hegemônicos em cada fase da história moçambicana. Para sustentar as análises efetuadas ao longo do texto, recorremos à pesquisa bibliográfica sobre o assunto, tanto de autores moçambicanos como de estrangeiros. Foram consultados livros, artigos, teses e relatórios que abordaram a realidade do país durante a última fase da presença colonial portuguesa em Moçambique. Analisou-se os primeiros dez anos de independência de Moçambique, ou seja, quando foi implantada a socialização do campo como estratégia de desenvolvimento do espaço rural.

PALAVRAS-CHAVES: organização do espaço, território, Moçambique

\section{ABSTRACT}

The Mozambican countryside went by transformation in the form of organization of the residential and productive space according to the State's interests, either was colonial or by the winner party emerged from the national liberation struggle. With the article we intend to analyze how the domain of systems of objects and actions on the space was fundamental to achieve the interests of hegemonic actors at each stage of Mozambican history. To support the analysis made along the text, we fell back upon the bibliographic produced on the subject, either by Mozambican and foreign authors. We consulted books, articles, thesis, reports that addressed the reality of the country during 
the last phase of the Portuguese colonial presence in Mozambique. It was analyzed the first ten years of independence of Mozambique, when the socialization of the field was introduced as the strategy of development of the rural space.

KEYWORDS: space organization, territory, Mozambique

\section{RÉSUMÉ}

Le rural du Mozambique a passe par dês transformations dans La forme d’organisation de l'espace résidentiel et produtif em raison dês intérêts de l'Etat, que ce soit Le colonial comme Le quelqu'estat paru pendant la lutte de la libération nationale. Avec l'article nous voulons analyser comme le domaine des systèmes des objets et des actions sur l'espace, est fondamental pour la matérialisation des intérêts des acteurs hégémoniques dans chaque étape de l'histoire du Mozambique. Pour le soutien de l'analyse développée au long du texte, on a fait de la recherche dans les bibliographies produite à cesujet, tant des auteurs du Mozambique comme des auteurs étrangers. Nous avons consulté des livres, articles, rapports qui ont analysé la réalité du pays pendant la dernière phase de la présence coloniale portugaise au Mozambique. Donc, les dix premièresannées d'indépendance du Mozambique ont été analysé es exactement quand la socialisation du champ a été introduite comme stratégie de développement de l'espace rural.

MOTS-CLÉS: Organisation de l'espace, territoire, Mozambique 


\section{INTRODUÇÃO}

O rural moçambicano passou por transformações na forma de organização do espaço residencial e produtivo em função dos interesses do Estado, quer seja o Estado colonial ou aquele surgido da luta pela libertação nacional. A organização espacial da família rural moçambicana apresentava como característica ser um assentamento rural disperso, em que as famílias se agrupavam em torno de uma liderança familiar, que poderia ser também o responsável da "família alargada" ${ }^{1}$. O espaço residencial sempre esteve próximo do espaço produtivo, e dele era retirado o suficiente para as necessidades do grupo familiar, mas que em tempos de carência da produção agrícola recorria à solidariedade do grupo. Esta forma de organizar o espaço produtivo e residencial, principalmente criando-se condições para a sua relativa autonomia, permitia que a reprodução da família (e/ ou do grupo) estivesse alicerçada nas relações internas do grupo. Desta forma, a produção do excedente agrícola visava, principalmente, a satisfação das necessidades alimentares para a reprodução sociocultural do grupo.

Dominar esta forma de organização do espaço e submetê-la aos ditames do interesse do Estado passou a ser a estratégia utilizada pelas novas formas de administração do então território moçambicano, que comportava, em si, vários territórios. A transformação dos territórios "tradicionais" em território moderno, delineado pela Conferência de Berlim (1884-1885), impôs a introdução de mecanismos de submissão dos territórios em favor da metrópole. A incorporação dos modos de produção não capitalistas ao modo de produção capitalista provocou alterações profundas, não só na subordinação dos modos de produção não capitalistas, como também ao nível da organização do espaço rural. A metrópole passou a influenciar a forma de organização e de ocupação do espaço da família rural como forma de responder aos seus interesses.

Passados cerca de cinco séculos sob o domínio português, movimentos de reivindicação de autonomia e de autodeterminação começaram a manifestar-se, exigindo a independência do território moçambicano. Alcançada a independência em 1975, o novo Estado emergente introduziu formas de administração do território moçambicano que quebravam as antigas modalidades de administração. Para responder aos seus objetivos, as formas de organização e de ocupação do espaço da família rural, bem como do modo de produção, deveriam passar por profundas alterações, com o objetivo de impedira acumulação. A socialização do campo foi a estratégia de desenvolvimento adotada pelo movimento saído vitorioso da luta pela independência de Moçambique, ou seja, a Frente de Li-

Para o contexto moçambicano, a família alargada é aquela que incorpora, para além de pai, mãe e filhos, outros familiares, como tios, primos, sobrinhos, avós e mais membros. 
bertação de Moçambique (FRELIMO). A estratégia de desenvolvimento traçada pelo governo da FRELIMO tinha como meta superar o subdesenvolvimento herdado da colonização e implantar formas coletivas de vida, de produção e de consumo. O ano de 1990 foi definido como o limite de tempo máximo para o alcance desses objetivos.

Contudo, em meados da década de 80, fatores conjunturais (e quiçá estruturais), de ordem interna e externa, comprometeram o sonho moçambicano e, o neoliberalismo surgiu como a nova estratégia de desenvolvimento. Pressionado pelas agências internacionais (Banco Mundial e Fundo Monetário Internacional) o país foi "forçado" a implementar as reformas econômicas, visando adequar a economia nacional à economia mundial, submetida à exploração do capital internacional, fundamentalmente de origem ocidental.

O presente artigo busca aprofundar ainda mais a análise que efetuamos num outro momento em que abordamos principalmente o papel do Estado em relação à agricultura familiar. Naquele momento, analisamos como a política de Estado primou por outras formas de (re)produção que eram contrárias à "exploração do homem pelo homem” e onde a agricultura familiar foi considerada como um vestígio da herança colonial capaz de conduzir à formação do pequeno burguês. No $\operatorname{artigo}^{2}$ defendemos que o acesso da família rural à terra esteve condicionado aos interesses do Estado. Nele dividimos a análise em três momentos, sendo que o primeiro vai da proclamação da independência (1975) até as primeiras crises na estratégia de socialização do campo adotada pela FRELIMO. O segundo período (1981/82 a 1987), denominamos de período de transição, pois coincide com a fase em que o país começou a rever a sua política de desenvolvimento rural, abre as portas para a iniciativa privada e revê, aparentemente, a sua posição em relação à agricultura familiar. Em resumo, é o momento em que o país começou a perceber que não tinha mais condições para sustentar o sonho da formação de um país socialista (ou pelo menos de orientação socialista). O terceiro período inicia com a introdução dos Programas de Reabilitação Econômica e vai até os nossos dias.

Neste artigo pretendemos concentrar a nossa análise no primeiro e no segundo período, abordados naquele artigo. Analisaremos como o domínio dos sistemas de objetos e de ações sobre o espaço foi fundamental para a materialização dos interesses dos atores hegemônicos, em cada fase da história moçambicana. Ou seja, o que nos interessa é a forma como o território foi usado para o alcance de determinados fins. Abordaremos as estratégias utilizadas,tanto pelo estado colonial como pelo governo da FRELIMO, para organizarem o território de acordo com os seus interesses. Para sustentar as análises efetu-

MATOS, Elmer A. C. de; MEDEIROS, Rosa M. V. “Acesso a terra e exploração mineira em Moçambique: que implicações para as comunidades locais". In: Campo e Território: revista de geografia agrária, v.9, n.17, p. 559-621, abri. 2014 
adas ao longo do texto, recorremos à pesquisa bibliográfica sobre o tema tanto de autores moçambicanos como de autores estrangeiros. Foram, portanto,consultados livros, artigos, teses e relatórios que abordaram a realidade do país durante a última fase da presença colonial portuguesa em Moçambique, quando então foram introduzidas políticas coloniais mais concretas para a ocupação efetiva do país. O período também abrange a análise dos primeiros dez anos de independência de Moçambique, quando teve início a socialização do campo como a estratégia para o desenvolvimento do meio rural.

\section{A HERANÇA COLONIAL}

As transações comerciais e a ocupação de frações do atual território moçambicano por parte de Portugal é anterior a Conferência de Berlim (1884-1885), quando foi definido que as potências imperialistas detentoras de terras na África, deveriam delimitar os espaços de ocupação no continente o que culminou com a definição dos atuais limites dos territórios nacionais dos países africanos. Para Portugal, isso significou a ocupação militar, administrativa e econômica do território moçambicano.

Localizado na costa oriental da África, o território moçambicano faz fronteira, de Norte a Sul, com os seguintes países: Tanzânia, Malaui, Zâmbia, Zimbábue, África do Sul e Suazilândia. À leste é banhado pelo Oceano Índico, com uma faixa litorânea de mais de $2700 \mathrm{~km}$ de extensão (mapa 1). Apesar de a conferência ter dado indicações claras para uma ocupação efetiva por parte das potencias imperialistas, constata-se que Portugal só conseguiu implantar o sistema colonial, dominando as resistências internas, apenas em finais da segunda década do século XX. 


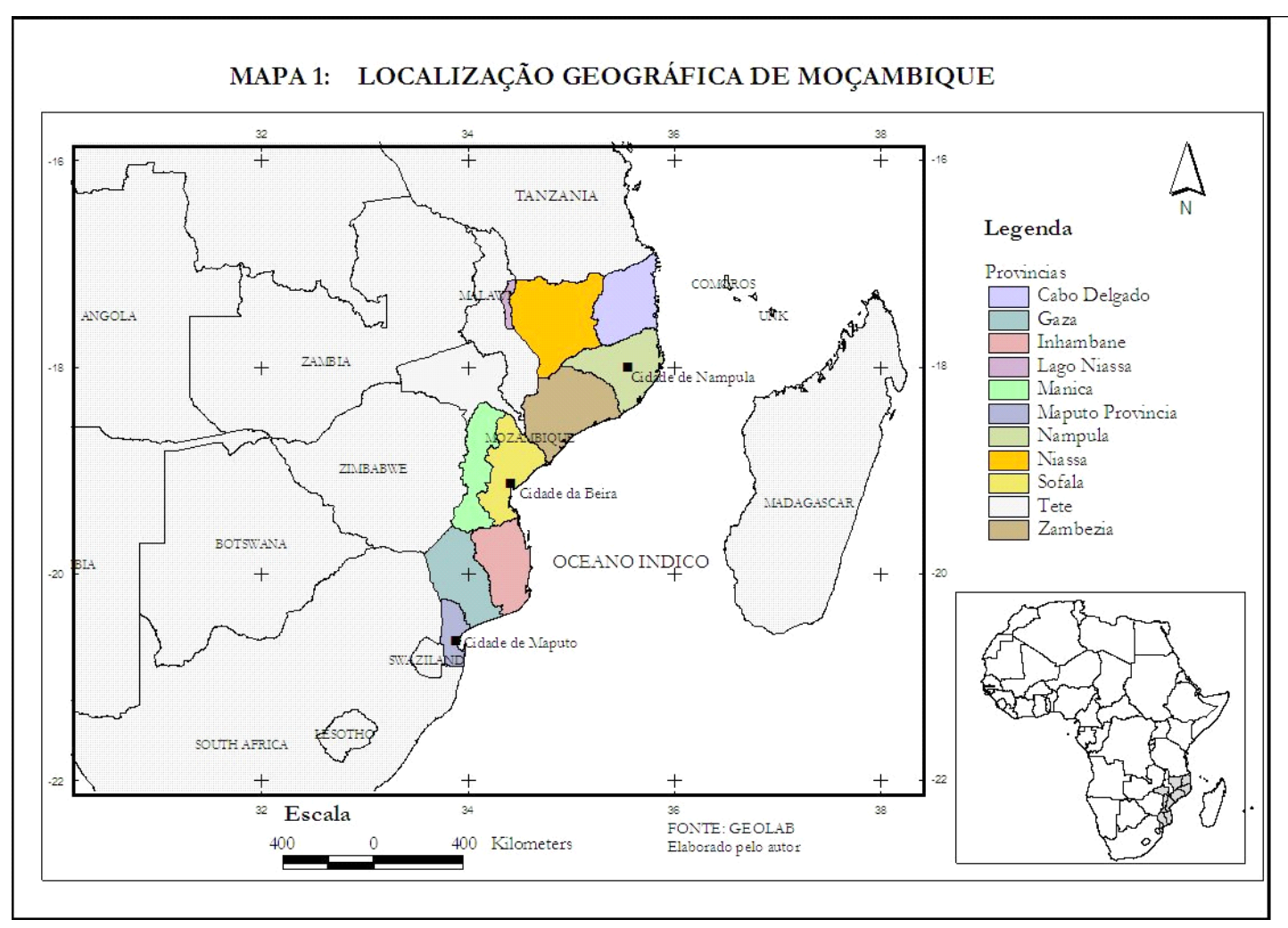

Como Portugal era frágileconomicamente, sem condições financeiras para custeara ocupação militar e administrativa de Moçambique, optou por uma administração indireta de determinadas províncias (HEDGES, 1999). Desta forma, no norte do país, as atuais províncias de Niassa e Cabo Delgado foram arrendadas à Companhia do Niassa. As províncias de Manica e Sofala passaram a ser administradas pela Companhia de Moçambique. Essas companhias, denominadas de Majestáticas ${ }^{3}$, eram de capital estrangeiro, detendo os poderes econômicos, administrativos e militares. As províncias de Tete e Zambézia ficaram sob a responsabilidade conjunta do Estado português e de companhias que arrendaram os antigos prazos ${ }^{4}$. O Estado português apenas administrava diretamente as províncias do sul de Moçambique (Inhambane, Gaza e Maputo) e a província nortenha de Nampula.

A incorporação da agricultura familiar como forma principal de acumulação do capital, na nova economia colonial, foi fundamental, pois era preciso que a produção familiar pudesse alimentar o consumo local, bem como produzir para a exportação. A população moçambicana foi forçada a trabalhar nas plantações ao mesmo tempo em que deveria produzir o suficiente para alimentar os trabalhadores das agroindústrias. É impor-

3 Companhias Majestáticas eram também companhias "soberanas", geridas por capital estrangeiro, com poderes sobre o "território" arrendado.

${ }_{4}$ Os prazos eram grandes extensões de terra em Moçambique em que Portugal concedia com o objetivo de povoamento de portugueses de origem europeia que se aventuravam a procura de ouro. Geralmente a terra era concedida a uma mulher europeia, casada com um colono europeu, com a obrigação de residirem e cultivarem no espaço concedido (MOSCA, 2005). 
tante ressaltar que as culturas desenvolvidas nas plantações tinham como destino a exportação e, eram constituídas principalmente pelas culturas de cana-de-açúcar, sisal, coqueiros, caju e chá.

A implantação dos plantios destinados à exportação foi responsável por expulsar as famílias rurais das terras mais férteis. Essas famílias foram instaladas em áreas consideradas como de reservas indígenas, ficando sujeitas às decisões do governo colonial. Negrão (1995) destaca que essa fase foi também caracterizada pelo recrutamento compulsório de moçambicanos para trabalharem nas plantações, como também pela obrigatoriedade de pagamento do imposto em moeda corrente.

A partir de 1930 Portugal redefine a sua política de administração do território moçambicano, colocando-o diretamente a serviço dos interesses da metrópole.Segundo Hedges (1999, p.35), Portugal estabeleceu "algumas das bases do seu 'nacionalismo econômico"'. Juntamente com Negrão (1995) são unânimes em afirmar que é neste período que a política portuguesa direcionada à agricultura concentrou esforços para a produção de algodão e arroz, colocando-ascomo culturas obrigatórias. É importante destacar, como faz Negrão (1995), que neste período houve uma preocupação por parte de Portugal em garantir terra às famílias rurais, com o objetivo de produzirem, principalmente, algodão e arroz. A administração direta do território moçambicano levou Portugal a não renovaçãodos contratoscom as companhias majestáticas.

A administração direta do Estado colonial configurou-se de formadiferente ao nível das três regiões do país, pois algumas áreas estavam cedidas às companhias majestáticas. Desta forma, o Sul foi reservado como fonte de mão de obra barata para a África do Sul e Zimbábue. Segundo Araújo (1989) foi assinado um acordo entre o governo português e o sul-africano, regulado pela Convenção de 1909, renovado em 1928, com o nome de Acordo do Transval. O acordo garantia o emprego de um significativo número de moçambicano nas terras da África do Sul e, Transval, nome de uma das províncias da Republica da África do Sul, deveria utilizar as estradas de ferro e o porto de Maputo em cerca de 50\% das suas necessidades. O acordo também especificava que, "para cada trabalhador, a metrópole colonial recebia, diretamente, uma parte significativa dos salários (60\%) em ouro, a um preço fixo muito razoável” (ARAÚJO, 1989, p.36).

Ainda na região Sul do país desenvolveram-se pequenas e médias empresas agrícolas de colonos, concentradas no vale do Limpopo. Essas empresas tinham como principal objetivo abastecer com alimentos os mercados urbanos, especialmente a comunidade não africana (CASTEL-BRANCO, S.D). 
A região central do país foi fortemente marcada pela presença de plantações de chá e de açúcar. Nesta região, o agricultor familiar era forçado a vender a sua força de trabalho, além de estar obrigado a dedicar-se à produção das culturas obrigatórias do algodão e do arroz. Dessa forma, houve conflito no processo de alocação da força de trabalho destinadaou para as plantações ou para as culturas obrigatórias, forçando a mecanização como forma de minimizar o conflito (CASTEL-BRANCO, S.D).

Para a região norte do país, o agricultor familiar também foi obrigado a produzir algodão e caju para a exportação. Aqui, como não existiam as plantações, os camponeses de forma compulsória produziam nas suas áreas de cultivo as culturas obrigatórias para depois comercializarem a preços fixos com as empresas monopolistas ou com o Estado colonial (IDEM).

Das características apresentadas para as três regiões do país, pode-se perceber o domínio de três principais modalidades de produção agrária: a primeira é aquela desenvolvida pelas famílias rurais, onde conjugam culturas de subsistência com as destinadas ao mercado(algodão, arroz e caju), quer seja o mercado interno ou externo; a segunda é aquela que é dominada pelas plantações de larga escala, voltadas principalmente para a exportação. Este tipo de agricultura, segundo o Center for DevelopmentResearch (1978) era dominada por empresas estatais; e a terceira produção agrícola é aquela praticada pelos pequenos e médios colonos, principalmente de imigração portuguesa, cujo destino principal da sua produção é o abastecimento do mercado urbano, principalmente de população não africana.

Esta forma de ocupação do soloorganizada para responder aos interesses do capital colonial, levou Araújo a desenhar um padrão de ocupação espacial diferente do padrãoanterior à presença colonial. Para Araújo (1989) a presença colonial não alterou significativamente a ocupação do espaço rural, isto é, não houve uma transição do povoamento rural disperso para o agrupado. Contudo, ocorreram alterações no padrão rural disperso, onde as ocupações dispersas de fraca densidade eram interrompidas por alguns adensamentos, resultantes da política colonial de melhor aproveitamento e controle da população rural moçambicana. Senão vejamos, se a introdução da agricultura empresarial ou dos colonos, que necessitava de extensas áreas para a sua prática, levou a expulsão dos nativos para terras marginais ou dispersou-os em áreas marginais, também funcionou no sentido inverso, atraindo o nativo. Isto é, ao mesmo tempo em que as plantações empresariais e as áreas de cultivo dos colonos necessitavam de terra em quantidade e qualidade, elas também necessitavam de mão de obra, principalmente barata. Isso se constituía como "atração" dos nativos que se localizavam ao redor dessas áreas, para "vender" sua força de trabalho. 
É importante ressaltar que o fator de atração que se apresenta não está exclusivamente ligado à possibilidade de encontrar um emprego que possa satisfazer as necessidades familiares, mas sim ao fato de o agricultor familiar ter que pagar o imposto ou estar forçado a trabalhar (Chibalo) nas plantações, como definia a política do Estado colonial. Logo, a sua localização junto às áreas de produção dominadas, quer pelas plantações quer pelos colonos, era uma necessidade para o cumprimento das obrigações fiscais a que estavam sujeitos. É então, com base nessas necessidades, que o padrão de ocupação do espaço rural passa a apresentar um povoamento disperso, intercalado por alguns adensamentos populacionais.

A organização do espaço residencial e do espaço produtivo continuou a mantê-los próximo um do outro. As transformações ocorridas no modo de produção não provocaram mudançascom a organização do espaço residencial e produtivo. A principal preocupação do governo colonial foi forçar os agricultores a produzirem, nas suas próprias áreas de cultivo, as culturas obrigatórias, com a carga de todos os riscos de sua produção. Contudo, o governo colonial fornecia aos agricultores familiares os insumos necessários, muito embora os prejuízos que pudessem advir de uma condição climática adversa ficassem na responsabilidade dos agricultores. Todavia, estes tinham que vender a sua produção às instituições definidas pelo Estado, que comprava a preços fixos e baixos, se comparadas com a média dos países da região. Para forçar os agricultores a desenvolver as culturas obrigatórias, os salários e os rendimentos auferidos pelos trabalhadores eram bastante baixos, permitindo pagar apenasparte do imposto. Ao mesmo tempo, eram criadas as condições para que a produção agrícola familiar não rendesse mais do que o necessário, forçando a sua ligação permanente com a terra.

A importância de manter o agricultor rural moçambicano ligado à terra era fundamental para a sua maior exploração, pois só assim ele se manteria migrante e dependente do trabalho assalariado. E, isso só poderia ser possível graças ao aparato de repressão e uso sistemático da violência (CASTEL-BRANCO, 1984; O’LAUGHLIN, 19995; ALMEIDA SERRA, 1991). Ao manter-se o agricultor ligado à terra obrigava-o a ter que se sustentar a partir dessa atividade como fonte de sua reprodução social, ao mesmo tempo em que era produtor das culturas que respondiam às necessidades do mercado. Como o agricultor tinha acesso à terra, mesmo que fosse menos fértil, a venda do excedente produzido era determinadopelo Estado com preço fixo e barato. Isso tornava a agricultura familiar insuficiente para a reprodução social e para responder às obrigações fiscais impostas(imposto ao Estado colonial). Dessa forma, o agricultor tinha que se sujeitar ao trabalho assalariado, mal pago, mas que era uma fonte de rendimento importante para financiar os fato- 
res de produção agrícola e para garantir o pagamento de impostos. Com mão de obra barata garantida ao setor empresarial, a mesma era migrante e sazonal, dependendo das necessidades do mercado interno e externo. A esse respeito, Castel-Branco argumenta que,

De forma a garantir que a força de trabalho se mantivesse barata, o Estado tinha que assegurar que ela se mantivesse migrante. Foi introduzida a caderneta para obrigar os trabalhadores a regressarem ao campo. Foram tomadas precauções para que a exploração do campesinato não destruísse completamente a agricultura familiar nem pusesse em risco a sobrevivência física dos trabalhadores. De forma a garantir a manutenção dos baixos salários, o Estado organizou o monopólio no recrutamento de força de trabalho para o setor capitalista local, controlou as atividades da WENELA (empresa monopolista recrutadora de força de trabalho nas minas da África do Sul), assinou rígidos acordos com a África do Sul e a Rodésia do Sul, para impedir a livre circulação populacional e de mercadorias através das fronteiras. Desta forma, o representante típico do Estado colonial junto do campesinato era o recrutador da força de trabalho. A rentabilidade da maioria das empresas capitalistas dependia da realização, pelo Estado, desta tarefa (CASTEL-BRANCO, 1884, p.9).

Portanto, o papel que a agricultura familiar desempenhava na economia colonial era bastante significativo, pois além de produzir para a exportaçãoproduzia alimentospara a população urbana. Em relação às principais culturas de exportação no período de 1971 a 1973, Almeida Serra (1991) coloca que o caju exportado vinha exclusivamente da agricultura familiar. Já em relação ao algodão, constata-se que era cerca de 2/3 que provinha da produção familiar. Apenas o açúcar é que era produzido pelas grandes plantações.

Alberts (1983, p.9) também evidenciou o papel desempenhado pela agricultura familiar, ao destacar que os ganhos obtidos com a exportação em 1961 e 1973, eram de 90\% e $82 \%$ respectivamente.Esses ganhos derivavam da agricultura e, "largas partes desses produtos exportados provinham do setor familiar".

Araújo (1989, p.338) constatou que em 1970 as explorações familiares ocupavam 97\% das unidades agrícolas existentes, apesar de em termos de superfície ocupada não ultrapassarem os $45 \%$ (43,38\%). Isso pode ser explicado pelo fato das unidades familiares serem, normalmente, inferiores a três hectares, o que contrasta com as áreas ocupadas pelas plantações que ocupavam extensas áreas e estavam destinadas exclusivamente a culturas de exportação.

Os autores citados mostram a importância deste setor para a economia colonial portuguesa. Para Hedges (1999) a estratégia da produção do algodão pelo setor familiar, respondia aos interesses da indústria têxtil portuguesa, num momento em que a produção no mercado mundial entrava em crise devidoa Segunda Guerra Mundial. Essa estratégia permitiu ao governo colonial aumentar a sua produção e comprar o produto a preços bem baixos, se comparados com a média praticada por outras potências. 
Para melhor explorar o território moçambicano, o governo colonial o estruturou de acordo com as suas necessidades. Se por uma lado colocou determinadas regiões a serviço da colônia portuguesa, através da exploração do algodão e de outras culturas de rendimento, por outro ladocolocou-se ao serviço dos países vizinhos, com destaque para a África do Sul e o Zimbábue (antigamente Rodésia do Sul). Esta forma de organização do território nacional não permitiu que se desenvolvesse uma economia verdadeiramente a serviço do território nacional.

Alberts (1983), Araújo (1989) e Almeida Serra (1991) consideram que o governo português definiu que a economia moçambicana se alicerçaria numa economia de serviços. A prestação de serviços de transporte ferro-portuário e de fornecimento de mão de obra barata permitia ao governo colonial colocar o país a serviço da África do Sul e do Zimbábue. Araújo (1989) destaca que os serviços ferro-portuário e a exportação da mão de obra eram as mais importantes fontes de acumulação da economia colonial moçambicana, pois representavam três quartos do PIB. O autor considera que essa dependência econômica se acentuou na década de 60 com a participação do capital internacional sul-africano e de países Ocidentais na construção da barragem de Cahora Bassa, que tinha como principal objetivo fornecer energia elétrica às indústrias sul-africanas.

Outro fator a considerar é a localização geográfica de Moçambique, em relação aos seus principais parceiros comerciais, como a África do Sul e o Zimbábue, que permitiu que o governo colonial proporcionasse condições para a abertura ao capital internacional (principalmente o sul-africano e o inglês) e assim construir os portos e as estradas de ferro. O porto de Maputo, considerado economicamente viável para as transações comerciais da província do Transval na África do Sul, bem como as estradas de ferro, ficaram à disposição dos interesses sul-africanos. Almeida Serra (1991) colocaque já em 1926/27 o sistema ferro-portuário de Maputo foi dominado pelo tráfego internacional, em cerca de $90 \%$. O mesmo também se verificou para o sistema ferro-portuário da Beira, localizado na província de Sofala, centro de Moçambique, que visava responder às necessidades do Zimbábue (IDEM). Mais tarde, este sistema também passou a responder aos interesses da Zâmbia e do Malaui.

Araújo (1989, p.34-35) argumenta que como o capital investido nos portos e estradas de ferro eram principalmente sul-africanos e ingleses, constata-se que esses serviços quase que ficaram exclusivamente voltadospara atender aos interesses desses países. Em 1960, o autor, recorrendo a Battistini (1967), evidencia que o sistema ferro-portuário da Beira dominou o seu uso com mais de $80 \%$ do tráfego de produtos exportados e importados para o Zimbábue, Katanga e Niassalândia (atualmente Malaui). Para o caso do siste- 
ma de Maputo, o peso foi de 47\%. Tanto Araújo (1989) como Almeida Serra (1991) destacam que para o ano de 1973, dois anos antes do alcance da independência, esses sistemas continuavam a desempenhar um papel importante nas transações comerciais desses países, superando a ocupação de $80 \%$ do tráfego dos sistemas.

Outro aspecto importante dessa relação de dependência de Moçambique face aos dois países vizinhos se relaciona à exportação de mão de obra barata para esses países, com destaque para a África do Sul, que acolhia grandes contingentes de imigrantes para trabalhar nas minas de ouro e de carvão e, em alguns casos, nas plantações. Segundo Almeida Serra (1991), não eram apenas esses países que se beneficiam da mão de obra barata moçambicana, mas eram esses osque mais se beneficiavam em termos quantitativos.

O papel desempenhado pela exportação dessa mão de obra era bastante significativa ao nível das províncias da região sul do país, que fora reservada pelo governo colonial como reserva de força de trabalho. Também, algumas províncias do centro forneciam esse serviço, com menor impacto se comparado com as da região Sul. As famílias que conseguiam migrar para esses países a procura de emprego regressavam com importantes economias que poderiam ser aproveitadas para investir na agricultura, já que os salários pagosnesses países eram relativamente maiores que aquele oferecido em Moçambique, limitado pela sobrevivência. A migração para os países vizinhos se apresentava como uma oportunidade de melhorar a condição de vida, bem como permitia introduzir novos fatores de produção na agricultura, podendo ir um pouco além da subsistência. Para fortalecer o papel desempenhado por esse serviço, Almeida Serra (1991) demonstra que boa parte dos homens jovens, em idade ativa trabalhava nesses países. Em 1960 um terço da população ativa se encontrava nesses países e, em 1970 sereduziu para um quinto devido à queda da emigração para o Zimbábue.

Os ganhos nesta transação não beneficiavam completamente Moçambique, já que o acordo com esses países permitia que uma parte dos salários fosse paga diretamente aos mineiros e a outra fosse transferida ao governo português, em Lisboa, em forma de ouro. Para Almeida Serra,

\begin{abstract}
As contrapartidas financeiras do fluxo migratório constituíam outra fonte importante de recursos suscetíveis de acumulação. Porém, desta só uma parte aproveitava Moçambique já que o restante se traduziu numa acumulação de recursos financeiros da metrópole colonial para onde eram transferidas as receitas em divisas e em ouro que este movimento migratório proporcionava através de mecanismos aprovados em acordos estabelecidos entre Portugal e a República Sul Africana (ALMEIDA SERRA, 1991, p.325).
\end{abstract}

Neste contexto, a economia moçambicana esteve assentada nos ganhos advindos dos sistemas ferro-portuário, da mão de obra exportada e dos produtos agrícolas exportados. 
No meio de todo esse cenário econômico, constata-se que eram os agricultores familiares que mais garantiam que esses ganhos fossem obtidos, pois eram eles que trabalhavam como mão de obra barata na construção e funcionamento desses sistemas ferro-portuário, na força de trabalho barata nas minas de ouro e carvão nos países vizinhos e na produção dealimentos, tanto para alimentar a população moçambicana que trabalhava nesses sistemas, como produzindo para o mercado urbano e para a exportação.

Para Castel-Branco (S.D) o papel desempenhado pelo agricultor familiar foi preponderante para a construção do império colonial português, daí que a sua incorporação dentro do modelo de produção colonial, tinha como principais funções:

a. produzir matérias-primas baratas essencialmente para exportação, mas também para a indústria doméstica;

b. produzir alimentos baratos para o abastecimento de força de trabalho assalariada nas plantações, portos e estradas de ferro, construções e indústria transformadora;

c. garantir o fornecimento de força de trabalho para as empresas capitalistas; e

d. cobrir uma parte substancial dos custos de produção de força de trabalho por intermédio da produção familiar.

\section{A SOCIALIZAÇÃO DO CAMPO}

Após o alcance da independência, o governo da FRELIMO adotou uma política econômica, social e cultural que quebrava com os cerca de cinco séculos de dominação portuguesa, como também dos períodos anteriores à colonização, materializados numa estrutura feudal. Essas formas de gestão do espaço nacional deveriam ser alteradas, radicalmente, para uma novaque produzisse à formação do homem novo, numa sociedade nova, libertada sociedade feudal e colonial, produtora dohomem comunista.

Para a materialização desse objetivo, que seassentava na socialização do campo, visto que o grosso da população residia no campo (perto de 90\%) e dependia da agricultura de subsistência (quase 87\%) para a sua reprodução social, era, fundamental, que se alterassem as formas de povoamento. A família rural moçambicana estava organizada em povoamentos dispersos de fraca densidade, intercalado, por pequenas aglomerações em volta das áreas de cultivo dominadas pela agricultura de comercialização. Esta forma de organização do assentamento rural não oferecia ótimas condições para a socialização do campo.

A transformação do assentamento rural disperso para oassentamento agrupado, materializado na criação das aldeias comunais era a característica da nova forma de organi- 
zação do espaço residencial. Ao se transformar o espaço residencial era, também, fundamental que com ele se alterasse o espaço produtivo. Para que isso fosse possível, desvinculou-se o espaço residencial do espaço produtivo. Com ele, foram introduzidas novas formas de organização da produção, assumiu-se a necessidade de se passar para formas de produção mais avançadas, como as cooperativas de produção e as empresas agrícolas estatais (HERMELE, 1987; CENTRE FOR DEVELOPMENT RESEARCH, 1978; MACKINTOSH; WUYTS, 1987; ARAÚJO, 1989).

A forma como se organizam os objetos e as ações que vão se desencadear num determinado espaço é fundamental para o alcance dos objetivos dos atores que dominam o campo de forças do referido espaço. O governo da FRELIMO tinha o conhecimento de que só dominando a forma de organização do espaço rural implantaria a sua ideologia e, facilmente implementaria a sua estratégia de desenvolvimento rural. Para isso, o partido trazia uma experiência de dez anos de luta de libertação nacional, quando em função das necessidades da luta, as áreas libertadas da opressão colonial iam sendo organizadas em formas coletivas de vida e de produção. Essa experiência permitiu manter unido os guerrilheiros e a população que ia sendo liberta do domínio colonial.

A introdução de formas coletivas de vivência e de produção era, também, condiçãoimperiosa para desviar o foco da acumulação, que passaria do individual para o social. Se para responder aos interesses coloniais foi necessário alterar, ligeiramente, as formas de organização do assentamento, o mesmo também se verificaria para responder aos interesses da construção de uma sociedade socialista, onde o foco de luta se posicionava contra a acumulação individual e a consequente criação de uma pequena burguesia. Esta preocupação aparece patente em vários documentos do partido ${ }^{5}$ e em vários discursos do então presidente da FRELIMO e da República Popular de Moçambique. Um ano antes da independência, SamoraMachel, presidente da FRELIMO, em um discurso, referiu:

Africanizar o poder colonial e capitalista retira o sentido à nossa luta. Para que serviria a luta se continuássemos submetidos ao trabalho forçado, às companhias, às minas, mesmo se tudo estiver cheio de gerentes e capatazes africanos? Para quê o sacrifício se continuamos a vender o gado, o algodão, em feiras que só beneficiam os comerciantes, mesmo se estes forem africanos? Qual a razão de ser de tanto sangue, se no fim continuássemos submetidos a um Estado que, mesmo se governado por moçambicanos, só serve os ricos e os poderosos?(HERMELE, 1987, p.8)

\footnotetext{
É importante referenciar que para a realidade moçambicana, o partido FRELIMO está no governo desde a independência. Depois da alteração constitucional e com a realização de eleições gerais multipartidárias, a FRELIMO conquistou todos os pleitos eleitorais realizados no país. É o partido, através dos seus congressos, sessões e reuniões, que delineia a política econômica e social a serem adotadas pelo governo. Usaremos, ao longo do texto, a sigla FRELIMO para referir tanto o partido como o governo, por não apresentarem diferenciações para a abordagem que trazemos no artigo.
} 
Nesse discurso, percebe-se claramente que a luta contra formas individuais ou privadas de acumulação de riqueza seriam combatidas. Depois da proclamação da independência, Sérgio Vieira, membro sênior da FRELIMO e um dos ministros do governo, em um texto de reflexão sobre a formação do "Homem Novo", explica o porquê da adoção de formas coletivas de vida e de produção.

Quando nas zonas libertadas de Cabo Delgado se disse: "a castanha vai pertencer à cooperativa e deixar de pertencer ao fulano que até abandonou o território nacional"; quando se disse: "Não podes ter gente a trabalhar na tua machamba"; quando se disse: "vamos juntar as machambas e vamos trabalhar juntos", por razões muito concretas, pois para produzirmos temos que ter em conta os aviões e tem que haver alguém para vigiar o avião, o helicóptero e "eu cozinho com minha mulher não posso fazer isso" - foi quando dissemos aquilo, foi a partir destes pequenos elementos, que se iniciou a destruição da base material para a sobrevivência do feudalismo e para a emergência da burguesia (VIEIRA, 1979? p.28).

Apesar da referência à necessidade de organizar a população em formas coletivas de vida e de produção já ter sido implementada nas zonas libertadas, ela aparece como parte da estratégia do partido para conduzir o desenvolvimento rural moçambicano, nos dois principais encontros realizados pelo partido antes da proclamação da independência. O primeiro foi realizado em Mocuba, província da Zambézia, em fevereiro de 1975 e, o segundo foi em Marrupa, província do Niassa, entre os dias 29 de maio e 4 de junho. Nas conclusões desses encontros, como é citadopor Almeida Serra (1991) são abordados mais explicitamente a necessidade de aglomerar a população dispersa comoforma para ter acessoaos serviços de educação, saúde, abastecimento de água e luz, comunicações e outros. Isso se devia pelo fato de tornar-se, quase impossível, beneficiar a toda a população com esses serviços se continuassemvivendo em povoamentos dispersos.

As informações provenientes desses dois eventos do partido não ofereciam os instrumentos necessários para a implementação dessa estratégia. Foi só a partir da VIIIa Sessão do Comité Central da FRELIMO, realizada em fevereiro de 1976 que claramente se definiu a aldeia comunal como o eixo para o desenvolvimento do campesinato moçambicano (ARAÚJO, 1989; ALMEIDA SERRA, 1991). Nesse evento foram definidos os princípios gerais orientadores para a sua criação, bem como os objetivos e as formas de produção que segundo Araújo (1989) se resumem em: (i) a concentração deve ser resultado de uma atividade produtiva coletiva; (ii) produção coletiva e familiar não são contraditórias; (iii) deve haver um equilíbrio ecológico; e (iv) novas tecnologias de produção devem ser introduzidas gradualmente.

A socialização do campo, materializada nas aldeias comunais e nas formas coletivas de produção, foia forma encontrada pelo governo da FRELIMO para a organização do espaço residencial e produtivo que respondesse aos interesses do partido e do governo. No

6 Designação usada para se referir a campos de cultivo agrícola ou a roça. 
terceiro ano da independência já existiam em Moçambique 857 aldeias comunais, albergando $12 \%$ da população rural. Perto de $70 \%$ das aldeias comunais encontravam-se concentradas na província de Cabo Delgado, seguida das províncias de Nampula e Gaza, com 9\% para cada uma (tabela 1 ).

\section{Tabela 1: Evolução da população vivendo em aldeias comunais por província (\%)}

\begin{tabular}{l|c|c|c|c|c|c|c|c}
\multirow{2}{*}{ Províncias } & \multicolumn{7}{c|}{1978} & \multicolumn{4}{c}{ 1982/83 } \\
\cline { 2 - 9 } & $\begin{array}{c}\text { No de } \\
\text { aldeias }\end{array}$ & População & $\begin{array}{c}\text { \% da pop. } \\
\text { da província }\end{array}$ & $\begin{array}{c}\text { \%de aldeias } \\
\text { no país }\end{array}$ & $\begin{array}{c}\text { No de } \\
\text { aldeias }\end{array}$ & População & $\begin{array}{c}\text { \% da pop. da } \\
\text { província }\end{array}$ & $\begin{array}{c}\text { \% de aldeias } \\
\text { no país }\end{array}$ \\
\hline Cabo Delgado & 586 & 800000 & 88,0 & 68,4 & 543 & 815555 & 87,3 & 39,9 \\
\hline Niassa & 40 & 72000 & 16,2 & 4,7 & 63 & 163215 & 32,0 & 4,6 \\
\hline Nampula & 80 & 50000 & 2,6 & 9,3 & 260 & 154186 & 7,0 & 19,1 \\
\hline Zambézia & 13 & 10000 & 0,5 & 1,5 & 39 & 49220 & 2,0 & 2,9 \\
\hline Tete & 26 & 25000 & 3,6 & 3,0 & 41 & 137800 & 17,3 & 3,0 \\
\hline Manica & 9 & 4500 & 0,1 & 1,1 & 111 & 143541 & 25,4 & 8,1 \\
\hline Sofala & 13 & 10000 & 1,3 & 1,5 & 88 & 106139 & 12,6 & 6,5 \\
\hline Inhamabane & 5 & 2500 & 0,0 & 0,6 & 47 & 73352 & 7,0 & 3,5 \\
\hline Gaza & 80 & 180000 & 20,4 & 9,3 & 123 & 513312 & 50,9 & 9,0 \\
\hline Maputo & 5 & 4000 & 0,8 & 0,6 & 47 & 46440 & 8,5 & 3,5 \\
\hline País & 857 & 1158000 & 12,0 & 100,0 & 1362 & 2202756 & 20,0 & 100,0 \\
\hline
\end{tabular}

Fonte: Araújo (1989)

Os dados da tabela 1 demonstram que apenas três províncias concentravam perto de 90\% das aldeias comunais registradas no país em 1978. A maior concentração de aldeias comunais na província de Cabo Delgado pode ser explicada por ser lá onde começaram a surgir as primeiras zonas libertadas. Niassa e Tete são também outras províncias em que se encontra com exclusividade esse tipo de aldeia comunal (tabela 2). Para os casos de Nampula e Gaza, a maior concentração de aldeias comunais encontra explicações diferentes. Para a primeira, o surgimento está fortemente ligado à corrida para a concentração da população em aldeias comunais resultante do encontro de Marrupa, que criou ambiente para os responsáveis provinciais e distritais entrarem em competição para a sua implementação (ARAÚJO, 1989; ALMEIDA SERRA, 1991). Enquanto que para Gaza, constata-se que as inundações do rio Limpopo e Incomati aceleraram a criação de novas aldeias comunais, localizadas em áreas consideradas seguras em face de prováveis inundações (HERMELE, 1986; ARAÚJO, 1989). 
Para o ano de 1982/83 as três províncias passaram a albergar perto de $70 \%$ das aldeias comunais. Apenas a província de Nampula aumentou significativamente o seu peso relativo. A província de Gaza manteve o seu percentual e a provínciade Cabo Delgado foi a que perdeu. Em termos absolutos constata-se que todas as províncias do país ganharam mais aldeias comunais, com exceção da de Cabo Delgado (tabela 1). Esse aumento proporcionou o aparecimento de mais de 500 aldeias, passando a concentrar cerca de $20 \%$ da população rural do país.

Tabela 2: Origem da formação das aldeias comunais por província em 1982 (\%)

\begin{tabular}{|c|c|c|c|c|c|c|c|c|c|c|}
\hline \multirow{2}{*}{ Províncias } & Tipo 1 & Tipo 2 & Tipo 3 & Tipo 4 & Tipo 5 & Tipo 1 & Tipo 2 & Tipo 3 & Tipo 4 & Tipo 5 \\
\hline & \multicolumn{5}{|c|}{ Relação interprovincial (1978 } & \multicolumn{5}{|c|}{ Relação intraprovincial (1982) } \\
\hline Cabo Delgado & 86,4 & 26,1 & 0,0 & 91,3 & 9,1 & 12,3 & 31,9 & 0,0 & 56,5 & 0,2 \\
\hline Niassa & 10,8 & 5,3 & 0,0 & 4,4 & 72,7 & 13,0 & 52,0 & 0,0 & 22,0 & 13,0 \\
\hline Nampula & 0,0 & 42,2 & 0,0 & 0,0 & 0,0 & 0,0 & 100,0 & 0,0 & 0,0 & 0,0 \\
\hline Zambézia & 0,0 & 0,0 & 20,0 & 0,0 & 0,0 & 0,0 & 0,0 & 100,0 & 0,0 & 0,0 \\
\hline Tete & 2,8 & 0,1 & 4,0 & 2,2 & 18,2 & 13,0 & 0,7 & 26,7 & 46,6 & 13,0 \\
\hline Manica & 0,0 & 0,2 & 6,0 & 1,6 & 0,0 & 0,0 & 1,8 & 53,9 & 44,3 & 0,0 \\
\hline Sofala & 0,0 & 0,0 & 26,0 & 0,2 & 0,0 & 0,0 & 0,0 & 94,5 & 5,5 & 0,0 \\
\hline Inhamabane & 0,0 & 7,4 & 0,0 & 0,0 & 0,0 & 0,0 & 100,0 & 0,0 & 0,0 & 0,0 \\
\hline Gaza & 0,0 & 16,2 & 39,0 & 0,3 & 0,0 & 0,0 & 70,9 & 27,0 & 2,1 & 0,0 \\
\hline Maputo & 0,0 & 2,5 & 5,0 & 0,0 & 0,0 & 0,0 & 76,2 & 23,8 & 0,0 & 0,0 \\
\hline
\end{tabular}

Fonte: Araújo (1989)

Legenda

Tipo 1: Aldeia formada durante a luta de libertação nacional

Tipo 2: Aldeias formadas a partir da mobilização produção coletiva

Tipo 3: Aldeias resultantes de calamidades naturais

Tipo 4: Aldeias edificadas em antigos "aldeamentos"

Tipo 5: Aldeias formado pelos regressados da guerra de libertação nacional

Se analisado a formação das aldeias comunais ao nível das províncias, pode-se constatar que a mobilização ${ }^{7}$ e as calamidades naturais ${ }^{8}$ foram responsáveis pela formação do maior número de aldeias comunais existentes até ao ano de 1982 (tabela 2). É interessante

Halkes e Oppewal (1989, p.17) referem que em alguns casos o exercito foi utilizado para forçar a família rural a viver dentro das aldeias comunais, "deitam-lles fogo [nas habitações construídas fora das aldeias comunais], assim como aosceleiros, e os moradores têm que voltar para as aldeias fantasmas".

8 Em 1977 houve inundações dos rios Incomáti e Limpopo que afetaram a região Sul do país; em 1978 registrou-se cheias no rio Zambeze, afetando a região central do país, nomeadamente as províncias da Zambézia, Tete, Sofala e Manica; Em 1979 a região norte do país foi atingida pelo ciclone Justine; e em 1981 a região central e sul do país são fustigadas por uma seca intensa e prolongada. Todos esses eventos naturais acabaram por afetar no aumento da população em aldeias comunais como no aumento da fome, porém, cada um com a sua importância. 
notar que as províncias que mais foram afetadas pela guerra de libertação nacional apresentam os mesmos fatores de formação das aldeias comunais, ou seja, a herança da luta de libertação, os aldeamentos construídos pelos portugueses e a concentração dos regressos da guerra de libertação, são os responsáveis pela formação das aldeias comunais. Isto demonstra que o perfil dessas aldeias está bastante ligado às necessidades de uma associação para a conquista da independência ou como resultado da luta.

Analisando ainda por província, constata-se que três fatores são os principais responsáveis pela formação das aldeias comunais. A mobilização é a principal responsável em metade das províncias do país, destacando-se Nampula e Inhambane onde esse fator se apresenta como o único responsável. Nas provínciasrestantes, a mobilização influencia em pelo menos 50\%. As calamidades naturais são responsáveis em outrastrês províncias, destacando-se a província da Zambézia com 100\% e Sofala com 95\%. As aldeias comunais edificadas nos antigos aldeamentos são responsáveis nas duas províncias restantes (Cabo Delgado e Tete), além de se evidenciar quase 45\% na província de Manica, (tabela 2).

No geral, pode-se concluir que na região norte do país as aldeias comunais tiveram como principal causa para suaorigem os antigos aldeamentos e as mobilizações. Os antigos aldeamentos são, geralmente, as concentrações populacionais que o governo colonial criou para melhor controlar a população face à evolução da guerra de libertação nacional. Para a região central do país destacam-se também os antigos aldeamentos e o impacto das calamidades naturais. Nesta região evidencia-se a província da Zambézia em que as aldeias comunais existentes têm origem apenas nas calamidades naturais que afetaram essa província. É, também, esta província que apresenta o menor número de aldeias comunais e o menor percentual de população vivendo nela. Para Araújo (1989) a herança colonial, marcada pelas grandes plantações de chá e palmares, associado aos aspetos culturais poderão estar na razão da fraca aderência às aldeias comunais.

A região Sul tem seu cenário marcado pela mobilização e pelo impacto das calamidades naturais. Nesta região, esses dois fatores que originaram as aldeias comunais parecem ser diferentes, pelo menos teoricamente.Mas na prática, como nos revela Araújo (1989), há uma confusão nessa distinção, pois algumas aldeias que surgiram como resultado das cheias acabaram caracterizadas como sendo resultado de mobilização visto que ações mobilizadoras levaram a população a abandonar as suas terras de residência e de produção para assumiremuma nova forma de organização residencial e produtiva. Daí que o fator mobilização pode estar superestimado em prejuízo do impacto das calamidades naturais. 
A socialização do meio rural, a partir da criação das aldeias comunais e da criação de formas coletivas de produção, como as cooperativas, privilegiavam as áreas de cultivo comunais, mas sem considerar que a presença de áreas de cultivo familiar poderia conflituar com as coletivas. A planta das aldeias comunais apresentava a forma geométrica retangular ou quadrangular e, deveria comportar dedois a quatro bairros, onde cada um dos bairros deveria albergar cerca de 250 famílias. Os espaços, geralmente incluíam áreas de habitação (com dimensões de 30m x 40m), de agricultura familiar e de agricultura coletiva. As famílias que residiam nesses espaços deveriam concentrar-se nas áreas residenciais e cultivar nas áreas reservadas a prática da agricultura (ARAÚJO, 1989).

A escolha do novo local de assentamento era geralmente feito com a participação de alguns membros das comunidades. Esses locais deveriam ter em conta o equilíbrio ecológico, ou melhor, deveriam ter em conta os princípios que norteiam a criação das aldeias comunais (ARAÚJO, 1989; ALMEIDA SERRA, 1991). Nem sempre os princípios foram respeitados, quer devido à necessidade de apresentar mais novas aldeias comunais aos seus responsáveis, quer pelo fato das calamidades naturais irem criando condições para o aumento de população nas aldeias comunais e/ou pelo fato do tempo necessário para responder a uma ação forçada de criação das aldeias comunais não permitir que o processo fosse conduzido da melhor forma.

A socialização do campo, que era a estratégia de desenvolvimento rural traçada para o país, requeria que as famílias rurais se concentrassem e desenvolvessem formas de produção mais avançadas. Apesar de queum dos princípios da criação das aldeias comunais eranão ir contra a presença de áreas de cultivo familiar nas aldeias, constata-se que na prática tudo fazia crer que a luta contra a agricultura familiar estava declarada, tanto ao nível dos discursos ${ }^{9}$, da legislação ${ }^{10}$, assim como das diretrizes saídas dos congressos ${ }^{11}$ realizados.

Senão vejamos, com o alcance da independência, dada as indicações evidenciadas pelos discursos dos principais dirigentes do governo da FRELIMO, muitos agricultores estrangeiros não encontraram a garantia para continuarem a investir na agricultura. A nacionalização da terra, no dia da independência, foi um sinal claro que o governo mostra-

\footnotetext{
9 Almeida Serra (1991, p.418) descortina que a luta da FRELIMO contra a agricultura familiar era já antiga, pois mesmo Mondlane, primeiro presidente do partido, ainda durante a luta de libertação nacional já se recusava a aceitar que existisse diferenciação social. É com Samora, em seus discursos, que a luta contra a agricultura familiar ou produção individual é explicitamente combatida. Samora explica que a mobilização da população para o trabalho coletivo em detrimento do individual está ligado ao fato de se evitar "que a produção individual ou familiar degenere em propriedade exploradora originando classes de novos exploradores".

${ }^{10}$ A Constituição da República de 1975, a Lei de Terras de 1979 e a Lei de Minas de 1986 são bons exemplos da priorização de outras formas de produção, como a estatal e cooperativa em detrimento da individual ou familiar. A esse respeito leia Matos e Medeiros (2014).

${ }^{11}$ Os congressos da FRELIMO são os encontros mais importantes para a definição das políticas e estratégias sociais e econômicas a serem seguidas. Durante o período de implementação do socialismo em Moçambique o III $^{\circ}$ e IV $^{\circ}$ Congresso foram os que definiram quais as estratégias a serem seguidas pelo governo e/ou Estado.
} 
va quanto a sua filosofia em relação à política social e econômica a seguir. Com isso, houve abandono de várias áreas de cultivo pertencentes aos $\operatorname{colonos}^{12}$. Até ao início de 1976, Almeida Serra (1991) refere que o governo não havia decidido sobre o destino dessas áreas de cultivo.

A indecisão quanto às formas adequadas de gerenciar a situação de abandono das áreas de cultivo exploradas pelos colonos e, da definição de que política econômico-social seria adequada eleger para o desenvolvimento do espaço rural, proporcionou a entrega dessas áreas às cooperativas e ao Estado, isto é, criaram-se as machambas estatais e as machambas coletivas (HERMELE, 1987; ALMEIDA SERRA, 1991).

Almeida Serra (1991) argumenta que ainda nesse mesmo ano foi reestruturado o Ministério da Agricultura, criando-se a Direção Nacional para a Organização da Produção Coletiva (DINOPROC). O DINOPROC possuía dois setores, um com a responsabilidade de gerir as machambas estatais e o outro responsável pelo acompanhamento da produção das cooperativas. $\mathrm{O}$ autor constatou que esses dois setores apresentavam prioridades diferentes, onde o primeiro privilegiava o setor estatal com vista a torná-lomais influente e a principal veia do desenvolvimento agrícola, enquanto que o segundo, concentrava as suas atividades na organização política e na promoção e propaganda da nova filosofia política.

A ratificação da importância do setor estatal na estratégia de socialização do campo veio com a realização do III Congresso da FRELIMO, realizado em fevereiro de 1977, onde se definiu este setor como o dominante e determinante para o desenvolvimento agrícola e rural. Também, é nesse congresso que se tomam medidas importantes para a socialização do campo, assentada nas aldeias comunais e nas formas coletivas de produção (HERMELE, 1987; MACKINTOSH; WUYTS, 1987; ALMEIDA SERRA, 1991).

O III Congresso também definiu que, no processo de distribuição e/ou repartição das áreas de cultivo abandonadas pelos colonos, deveriam privilegiar-se as cooperativas, deveriam serconstruídas nas aldeias comunais. Aos camponeses, o tamanho da terra foi limitado a não mais que um hectare, principalmente nas áreas de irrigação (CEA, 1979; ALBERTS, 1983). Para além da limitação da área para a agricultura familiar, Araújo (1989) mostra que em várias situações eram atribuídas terras menos férteis à agricultura familiar, ou mesmo reduziam-se as suas parcelas em função da expansão da área das aldeias comunais ou das áreas de cultivo comum.

$\overline{12}$ Termo utilizado para chamar a população imigrante portuguesa que se estabeleceu em Moçambique devido à colonização portuguesa. 
Almeida Serra (1991) e Castel-Branco (S.D) argumentam que a marginalização do setor familiar abrangeu inclusiveo fornecimento de instrumentos fundamentaispara a produção, tais como as enxadas, catanas ${ }^{13}$, machados, etc. que deixaram de ser importadas, reduzindo-se drasticamente a quantidade existente no mercado interno. A preocupação do governo residia na importação de maquinaria (como tratores ${ }^{14}$, auto-combinadas ${ }^{15}$ e outros) e de insumos agrícolas (como fertilizantes e pesticidas), principalmente para abastecer as empresas agrícolas estatais, machambas estatais e as cooperativas. Essa medida encontrava-se dentro daquilo que era a filosofia do governo, acreditando que era necessário migrar da agricultura familiar para formas mais avançadas de produção, que neste caso seriam as cooperativas e as machambas estatais.

É importante destacar que apesar de se assumiruma política socialista, que de certa forma criava todas as condições para aniquilar o setor privado considerado explorador dos homens, o III Congresso não baniu este setor da política de desenvolvimento rural. Nesse Congresso apenasse criou as bases necessárias para submeter o setor privado ao programa do Estado, ou seja, o mesmoestaria fortemente acompanhado pelo Estado e/ou deveria seguir rigidamente as orientações da política do governo (CENTRE FOR DEVELOPMENT RESEARCH, 1978; ALBERTS, 1983; PITCHER, 2003).

A materialização da importância do setor estatal é destacada por Alberts (1983, p.29) ao revelar que existiam duas principais fontes de financiamento,Banco de Moçambique (BM) e o Banco Popular de Desenvolvimento (BPD). Segundo o autor,enquanto o Banco de Moçambique não concedia nenhum crédito às cooperativas, o Banco Popular de Desenvolvimento destinou cerca de $84 \%$ do seu crédito para as machambas estatais, apenas $8 \%$ para o setor das cooperativas e o restante foi para o setor privado, incluindo as empresas agrícolas, no ano de 1977. Grande parte do crédito do Banco de Moçambique foi destinadopara as grandes empresas agrícolas que apresentavam problemas de liquidez.

Mackintosh e Wuyts (1987, p.13) analisando a distribuição geral de crédito para os quatro setores, constataram que de 1977 a 1983, cerca de 90\% do investimento agrícola destinou-se para o setor estatal, $2 \%$ para o cooperativo e virtualmente nada para o setor familiar ${ }^{16}$. A não inclusão do setor familiar no apoio financeiro visava, de certa forma, im-

13 É um facão, com cabo em madeira e uma lâmina curvada, utilizado para desbastar mato.

${ }^{14}$ Almeida Serra (1991, p.534) aponta que "durante o ano de 1977 adquiriram-se cerca de 1200 tratores, dos quais 1000 foram distribuídos pelas empresas estatais agrícolas e os restantes 200 aos parques de máquinas do Ministério da Agricultura para serem alugados aos vários setores de propriedade, mas com prioridade para as machambas estatais".

15 São máquinas que desempenham mais de uma função, ou seja, combina duas ou três funções, como semear e adubar.

${ }^{16}$ É importante destacar que mesmo apesar do Estado ter direcionado grande parte do seu investimento para o setor estatal, constata-se que em 1982 este representava apenas $4 \%$ da área cultivada e o setor cooperativo 1\%. A maior parte da área cultivada estava na posse das famílias rurais, com cerca de $93 \%$. O setor familiar era responsável pela produção de cerca de $79 \%$ da produção agrícola e cerca de 10 milhões de moçambicanos dependiam desta atividade (ALBERTS, 1983, p.20). 
pedir que este setor se desenvolvesse, ao mesmo tempo em que se acreditava que era um setor atrasado e que com o tempo passaria para o cooperativo.

O governo apresentava inquietações em relação aos níveis de produção ${ }^{17}$, tanto para o mercado interno como paraa exportação, pois era ummomento de crise, onde os agricultores colonos haviam abandonado o país, a nova política econômica era menos atraente ao investimento estrangeiro, o país havia colocado sanções econômicas contra o regime de minoria branca da Rodésia do Sul (atual Zimbábue) em função das deliberações das Nações Unidas e a África do Sul reduzira drasticamente o número de contratados moçambicanos para trabalhar nas minas de ouro e de carvão ${ }^{18}$. Esses fatores provocaram uma redução na produção agrícola ao mesmo tempo em que se reduziu drasticamente o principal suporte econômico, fornecido pela prestação de serviços aos dois países vizinhos. $\mathrm{Pa}$ ra solucionar essa crise e, atendendo à ideologia do partido, o III Congresso definiu a estatização da economia como o caminho viável para a superação da crise e para fugir do subdesenvolvimento.

A mecanização da agricultura, a exploração de largas extensões de terras ${ }^{19}$, a formação de proletários que pudessem ser incorporados às empresas estatais e a transformação do setor da agricultura familiar em cooperativo se tornaram a prioridade do governo. $\mathrm{Pa}-$ ra isso, o governo investiu bastante nas empresas agrícolas estatais e muito pouco nas cooperativas. As cooperativas deveriam tertidoo apoio do setor estatal, principalmente em fatores e instrumentos de produção, ao mesmo tempo em que contariam com a participação "voluntária" dos agricultores familiares.

O processo de criação das cooperativas estava bastante associado à história da conquista da independência nacional. As razões que explicam a sua formação se encontram associadas. Alberts (1983) e o Centro de Estudos Africanos (1979) evidenciam três principais fatores que originaram as cooperativas, nomeadamente (i) as machambas abandonadas pelos colonos em decorrência daindependência que numa primeira fase foram ocupadas pelos agricultores familiares que passaram a cultivar coletivamente. Com o tempo, algumas dessas áreas foram apropriadas pelo Estado, passando a fazer parte das machambas estatais; (ii) as cooperativas coloniais, que também com a independência passaram a ser exploradas coletivamente pelos agricultores familiares; (iii) osprocessos de mobiliza-

\footnotetext{
${ }^{17}$ Os níveis de produção agrícola que o país apresentava eram insatisfatórios, o que levou o III Congresso a deliberar que até ao ano de 1980 se deveria alcançar os números de produção pré-independência (ALBERTS, 1983).

${ }^{18}$ Segundo Araújo (1989, p.65), em 1975 a África do Sul recrutou cerca de 118030 trabalhadores moçambicanos e em 1977 o valor baixou para 41394 moçambicanos. O número de contratados continuou a baixar e, em 1983 foi de 39731 trabalhadores.

${ }_{19}$ São exemplos os casos dos Complexos Agro-industrial de Angónia (Tete) e do Limpopo (GAZA) dominados por explorações estatais. O Centro de Estudos Africanos (1983) refere que em 1979 o Complexo Agro-Industrial de Angonia aumentou a área de exploração herdada do período colonial, passando a ocupar áreas de agricultores locais.
} 
ção promovidos pelasestruturas administrativas do Estado, como forma de se beneficiar do apoio estatal. Foi, em muitos casos, a forma que os agricultores (pequenos e médios) encontraram para se beneficiarem desse movimento (CENTRO DE ESTUDOS AFRICANOS, 1979, 1983; CASTEL-BRANCO, 1984).

O processo de evolução da formação de novas cooperativas foi relativamente acelerado, mas nem sempre acompanhou a evolução das aldeias comunais, visto que pelo menos em cada aldeia comunal deveria existir uma cooperativa. Analisando as informações apresentadas por Araújo (1989) pode-se perceber que a relação cooperativa e aldeia comunal nem sempre foi positiva, senão vejamos, em 1978 existiam cerca de 857 aldeias comunais em todo país e, nesse mesmo ano existiam apenas 180 cooperativas. Para o ano de 1982/83, o número de aldeias cresceu para 1362 e o de cooperativas passou para 375 . A distribuição geográfica também foi irregular e observaram-se casos em que existiam aldeias sem nenhuma cooperativa, aldeias com mais de uma cooperativa e, cooperativas não integradas a uma aldeia comunal.

O crescimento lento das cooperativas, se comparado ao ritmo de crescimento das aldeias comunais, pode estar associado ao fato desta forma de produção não responder às necessidades dos camponeses. Isto porque a produção e a produtividade eram baixas ${ }^{20}$, mesmo se comparada com a da agricultura familiar ${ }^{21}$. Estaera uma forma de produção que não fazia parte da característica do agricultor familiar "formatado" pelo processo de colonização. Essa herança colonial desempenhou um papel significativo na inserção real dos camponeses nas cooperativas, pois a necessidade do camponês ter o domínio completo da sua produção era fundamental ${ }^{22}$, ao mesmo tempo em que o agricultor familiar precisava do trabalho assalariado ${ }^{23}$ como uma forma de garantir a sua reprodução social ${ }^{24}$.

${ }^{20}$ Num estudo realizado por Alberts (1983) constata-se que em média os agricultores apenas cultivavam nas machambas da cooperativa uma área de cerca de 0,2 hectares. O CEA (1983)refere que a dependência que se mantinha em relação ao apoio que o Estado fornecia às cooperativas era significativa, chegando a registrarem-se casos em que quando o apoio demorava a chegar, os agricultores não trabalham.

${ }^{21}$ Almeida Serra (1991) faz uma comparação entre a produtividade do setor cooperativo e o familiar, mostrando que a produtividade do segundo era duas vezes maior que o do primeiro.

${ }^{22}$ Veja Almeida Serra (1991).

${ }^{23}$ As transformações introduzidas nos modos de produção do agricultor familiar pelo sistema colonial acabaram por deixá-lo quase dependente do trabalho assalariado, não só como fonte de pagamento do imposto, mas também como uma fonte de obtenção de bens de produção (charrua, bois, sementes) e bens de consumo (capulanas, sabão, açúcar, petróleo, etc.), a ponto do estudo realizado pelo Centro de Estudos Africanos (1979) considerar que a família rural precisava do mercado para se reproduzir.

${ }^{24}$ A ideologia do partido considerava que ao se transformar o setor agrícola familiar no setor cooperativo, os agricultores familiares não precisariam de ter um trabalho assalariado. No geral, as cooperativas e as aldeias comunais eram espaços onde se consideravam que o agricultor familiar encontraria todas as condições necessárias para o desenvolvimento da ideologia socialista, sem a "exploração do homempelo homem". Assim, haveria a união entre o camponês e o operário. Desta forma, os camponeses encontrariam emprego nas machamas estatais. Porém, isso não chegou a acontecer, as empresas estatais não foram capazes de fornecer emprego seguro e estável, isto é, a maior parte delas empregava sazonalmente, optaram pelas monoculturas e por uma relativa mecanização da agricultura, seguindo a mesma receita das empresas agrícolas coloniais (vide CASTEL-BRANCO, 1984; CENTRO DE ESTUDOS AFRICANOS, 1983; 1979). 
A relação que o agricultor familiar mantinha com o mercado havia se consolidado durante o período de colonização e, a socialização do campo pretendia manter o agricultor familiar apenas dependente das relações sociais e econômicas que se poderiam desenvolver nos espaços do povoamento agrupado, as aldeias comunais. Essa tentativa se baseavana capacidade do setor cooperativo e estatal conseguir absorver a mão de obra liberta do setor familiar. Porém, tanto as empresas estatais como as cooperativas não conseguiram absorver a mão de obra existente e, nem conseguiram dar o apoio necessário ao setor cooperativo para que obtivessem maiores rendimentos que o da agriculturafamiliar. Estudos realizados no distrito de Angónia e província de Gaza vieram demonstrar que tanto os pequenos como os médios agricultores que poderiam encontrar nas cooperativas um "balão de oxigênio", o mesmo não chegou a acontecer, visto que em muitos casos esses setores de atividades concorriam no acesso a mesma mão de obra, tinham um fraco apoio do Estado ${ }^{25}$ e apresentavam uma fraca organização interna. (CENTRO DE ESTUDOS AFRICANOS, 1979; 1983; CASTEL-BRANCO, 1984)

Muitas cooperativas foram criadas, principalmente, como formas de se atingir os números definidos pelas administrações provincial ou nacional, podendo, a partir delas, avaliar o nível de socialização do campo. Há exemplo de cooperativas criadas em que os cooperativistas não se consideravam como parte integrante dela ${ }^{26}$, apenas respondiam aos apelos das autoridades administrativas ${ }^{27}$ e, viam nelas uma forma de conseguir o apoio que $\mathrm{o}$ Estado canalizava às cooperativas ${ }^{28}$. Essa atitude encontra-se refletida, muitas vezes, nos casos em que se registram aumento de cooperativistas, mas a área e a produtividade continuavam a ser baixas ${ }^{29}$.

Os agricultores familiares integrados ao projeto de socialização do campo tinham que gerir os espaços de produção reservados à agricultura familiar e os reservados a agricultura

${ }_{25}$ Para além do investimento direcionado para este setor, constata-se que muitas vezes o apoio demorava a chegar - pois os recursos disponíveis, como os tratores eram insuficientes para responder aos setores estatal, privado e cooperativo - e os setores desenvolviam os mesmos tipos de cultura, o que tornava difícil atender a todos os setores ao mesmo tempo. Isso foi agravado pelo fato das cooperativas tornarem-se fortemente dependentes do uso da maquinaria das empresas estatais (CEA, 1983; CASTEL-BRANCO, 1984, ARAÚJO, 1989, ALMEIDA SERRA, 1991).

26 "A cooperativa de Angónia é normalmente vista mais como uma 'machamba do partido' do que como projeto para transformar a organização da agricultura familiar" (CENTRO DE ESTUDOS AFRICANOS, 1983, p.28).

${ }^{27}$ Um estudo realizado em Angónia, um dos distritos da província de Tete, pelo Centro de Estudos Africanos (1983, p.32) refere que "A direção da cooperativa foi indicada pelo atual secretário do grupo dinamizador [pessoal da estrutura administrativa do partido] do povoado como resposta ao apelo lançado em todo o distrito pelas estruturas partidárias, e com base no argumento de terem que ser os melhores camponeses do povoado, o que lhes ia permitir assegurar o seu funcionamento". Num outro estudo realizado na província de Gaza por Castel-Branco (1984, p.42), é possível encontrar cooperativas que tiveram essa origem, como é o caso da cooperativa Josina Machel, criada em finais de 1978, em que o seu surgimento deve-se ao "cumprimento da palavra de ordem do Partido de organizar o trabalho coletivo".

${ }_{28}$ Castel-Branco (1984, p.42) constatou que no ano de 1978 "os camponeses forammobilizados para a cooperativa para 'termos mais terra, sermos mais a trabalhar e recebermos o apoio do Estado"'.

29 Estudos realizados pelo Centro de Estudos Africanos (1979; 1983), Castel-Branco (1984) e Araújo (1989) elucidam melhor isso, tomando como base as três regiões do país. 
coletiva. Essa gestão também tinha implicações no tempo gasto e no esforço a ser dividido para a produção em cada um desses espaços. Araújo (1989) e Almeida Serra (1991) destacamque os agricultores não abandonaram as áreasanteriores de exploração da agricultura familiar, mesmo quando as aldeias comunais ofereciam esse espaço (figura 1). Para além das distâncias que deveriam ser percorridas entre a antiga machamba familiar e as providenciadas pelas aldeias comunais, os agricultores familiares tinham que encontrar no interior da família a divisão sexual e etária das atividades, isto é, um membro deveria trabalhar na machamba coletiva e o outro trabalhar na machamba familiar e/ou ser assalariado.

Figura 1: Organização espacial das aldeias comunais e a relação espaço residencial e produtivo

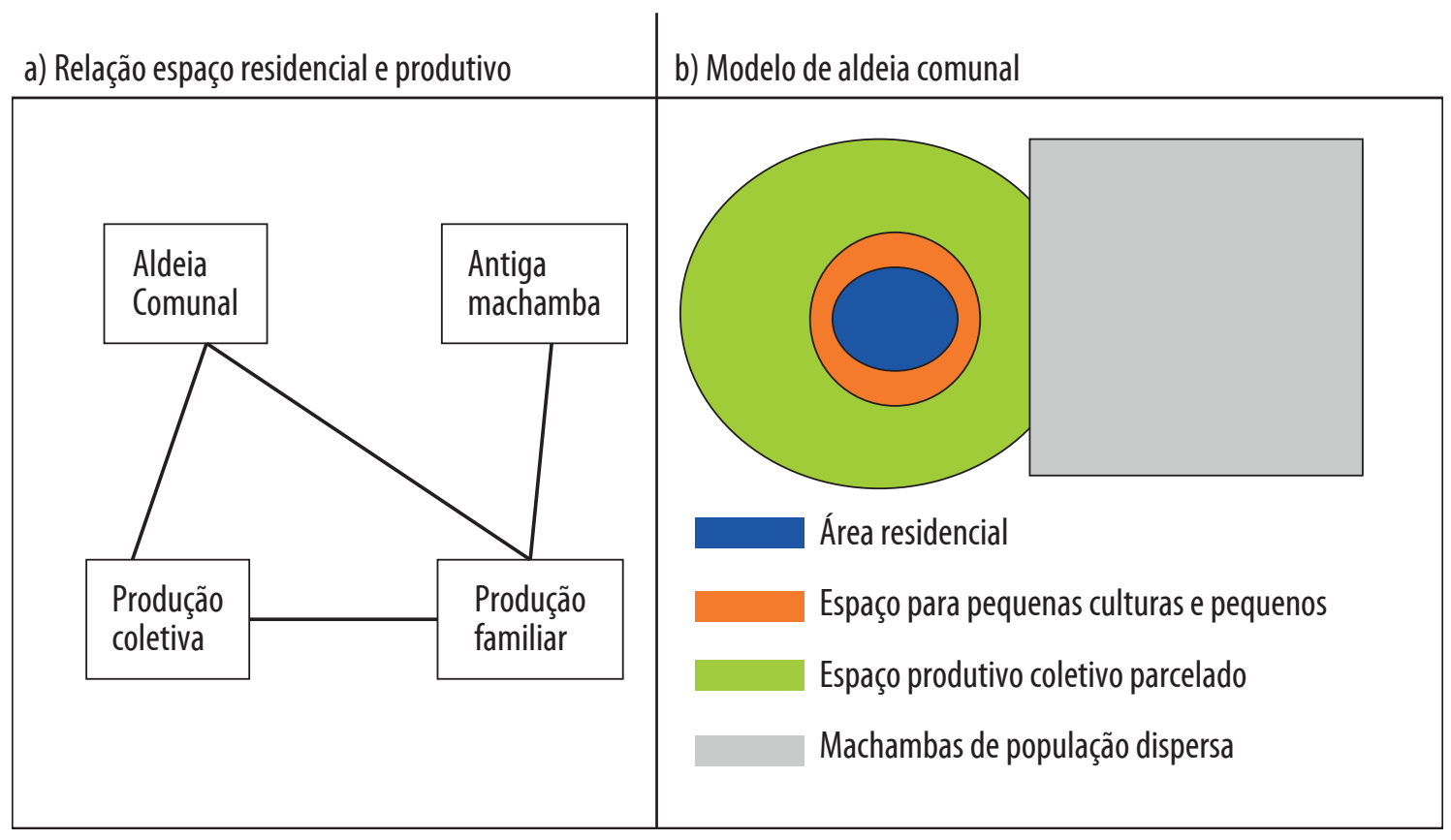

Fonte Almeida Serra (1991)

Fonte Araújo (1989)

Dependendo da importância que a cooperativa desempenhava no agregado familiar e das características herdadas do processo de colonização, constata-se que ou eram as mulheres que mais trabalhavam nas machambas coletivas ou eram os homens. No Sul e Centro do país constatou-se que as cooperativas eram dominadas por mulheres, enquanto os homens se dedicavam ao trabalho assalariado, quer seja na África do Sul, quer na machamba de outro agricultor ou ainda no espaço urbano. No norte, a situação era contrária, as cooperativas eram dominadas pelos homens. Isso pode ser explicado pelo fato das cooperativas desenvolverem culturas de exportação, gerando rendimento, o que mantinha os homens no comando desta atividade enquanto as mulheres se dedicavam a agricultura de subsistência (ARAÚJO, 1989; ALMEIDA SERRA, 1991; CENTRO DE ESTUDOS AFRICANOS, 1979, 1983; CASTEL-BRANCO, 1984). 
Apesar das cooperativas não responderem aos objetivos pelos quais foram criadas, como o aumento da produção e a transformação do setor familiar para o cooperativo, as mesmas desempenhavam, em muitos casos, uma importante fonte de recurso para os associados. Essa seria a razão para a presença de agricultores nela, principalmente os pequenos e os médios, cada um com as suas necessidades. Se para os agricultores médios essa era uma fonte de obtenção de bens e instrumentos de produção que escasseavam no mercado local, para os pequenos era a possibilidade que eles tinham de espreitarem a sorte de um trabalho nas machambas dos agricultores médios ou mesmo se beneficiarem em casos de problemas sociais gerados por morte ou doença na família (CASTEL-BRANCO, 1984).

Depois de atravessado os primeiros anos após a independência mergulhados numa crise econômica, a partir de 1978 os esforços do governo da FRELIMO começaram a dar resultados, ainda modestos ao nível dos indicadores econômicos, mas bastante importantes para se projetar um futuro mais ambicioso. Se os indicadores econômicos ainda apresentavam uma melhoria modesta, os indicadores sociais apresentavam resultados bastante significativos, pois o número de estabelecimentos de ensino e de saúde, bem como do pessoal que se beneficiou desses serviços mais que duplicou em cerca de três anos. Hermele (1988) e Braun (1988) referem que o crescimento modesto da economia havia chegado a níveis esperançosos em 1980 e 1981 e, foi nessa mesma década que se aprova o Plano Prospectivo Indicativo (PPI) que tinha como meta tirar o país do subdesenvolvimento em dez anos. Hermele (1988) destaca que as esperanças do plano alicerçavam-se, em parte, no fato do Zimbábue ter alcançado a independência em 1980, o que permitia retomar as relações comerciais e encerrar o apoio a RENAMO, já que esse país era o principal financiador desse movimento. Hermele, analisando o desempenho dos indicadores econômicos, constatou que

... a tendência da subida foi conjuntural, não tendencial, e foi basicamente causada por uma combinação de ótimas condições climáticas depois de vários anos de cheias, término das hostilidades com a Rodésia e o aumento de importações devido à disponibilidade de linhas de crédito, especialmente vindas dos países da OECD, como a França e a Itália ${ }^{30}$ (HERMELE, 1988, p.10).

As esperanças no projeto socialista encontravam entraves por falta de parceiros para financiar o PPI, pois os seus "parceiros naturais" (os países socialistas) estavam a passar por crises financeiras e sem condições para apoiarem financeiramente o projeto desenvolvimentista moçambicano. A não aceitação de Moçambique como membro do CO$\mathrm{MECON}^{31}$, excluía-o das linhas de crédito por essa via e, tornava o país cada vez mais dependente da África do Sul e também dos países capitalistas europeus. A possibilidade de

\footnotetext{
${ }_{30}$ Tradução livre de: "... the upturn was conjunctural, not tendential, and was basically caused by a combination of good weather conditions after several years of floods, termination of Rhodesian hostilities, and increase in imports due to availability of credit lines, especially from OECD countries like France and Italy".

31 O Pedido de Moçambique para ser membro do COMECON foi recusado em 1983.
} 
um autofinanciamento, que era uma das possibilidades de execução do PPI, também se tornava inviável (HERMELE, 1988; BRAUN, 1988; MARSHALL, 1990; 1992?). Marshall refere que,

Nos anos 70 Moçambique estava em posição de financiar o seu crescimento econômico por intermédio de uma mistura de exportações, ajuda externa e a grande diferença entre os preços de mercado de ouro e o preço estipulado no acordo Moçambique-África do Sul para recompensa pelos trabalhadores emigrantes. Mesmo quando em 1978 a África do Sul denunciou unilateralmente o acordo, Moçambique continuou a financiar o seu crescimento econômico por intermédio de exportações e vendas das reservas de ouro. Contudo, no início dos anos 80 Moçambique tinha acumulado uma considerável dívida. Enfrentava quedas enormes nas receitas resultantes da exportação assim que a guerra e os problemas de gestão invadiam as zonas rurais, reservas de ouro eram esvaziadas e se precisava cada vez mais de divisas para financiar a guerra e os preços cada vez mais elevados do petróleo e dos bens importados (MARSHALL, 1992?, p. 67).

As condições financeiras deterioravam-se a cada ano que passava, tornando-se impossível sustentar o projeto desenvolvimentista moçambicano. Os dados da tabela 3 demonstram o quanto a situação econômica se degradava cada vez mais. Braun (1988) e Marshall (1992?)mostramque o crescimento econômico chegou a ser negativo. Marshall (1992?) aponta que em 1985 o crescimento econômico chegou a ser de menos 20\%. Apesar dos esforços do país para reverter a tendência dos indicadores econômicos,determinadosfatores colocavam em cheque todos os esforços do governo, tais como:

O posicionamento da África do Sul com vista a desestabilizar a economia moçambicana. O país vizinho iniciou com cortes no número de moçambicanos contratados para trabalhar no seu país e depois, em 1978, deixou de pagar em ouro ao governo moçambicano. O número de turistas sul-africanos com destino a Moçambique parou abruptamente logo depois da independência e o uso do corredor do Limpopo (Maputo) reduziu para menos de 20\% (BRAUN, 1988). Com a independência do Zimbábue, a África do Sul passou a ser o principal financiador da RENAMO;

A década de 80 coincide com o intensificar da guerra civil, tendo afetado significativamente a economia do país. A RENAMO ${ }^{32}$ chegou a reduzir a frota de caminhões para cerca de $16 \%$ se comparado com o nível existente antes da independência; destruiu cerca de $45 \%$ da rede escolar e cerca de $31 \%$ da rede de saúde e metade da rede comercial rural (HERMELE, 1990). Esses ataques destruíram as bases para o desenvolvimento dos espaços rurais, afetaram a produção agrícola e deslocaram milhares de moçambicanos, tanto para as áreas urbanas, consideradas seguras, como para países vizinhos;

32 Em abril de 1988 o Departamento dos Estados Unidos da América acusou oficialmente este movimento de ser responsável por um dos mais brutais holocaústo contra o ser humano desde a Segunda Guerra Mundial (BRAUN, 1988) 
A combinação de uma seca severa (com implicações nos níveis de produção) coma aplicação de políticas agrícolas equivocadas (com impactos nos níveis de produção, tanto para o consumo como para a exportação), inviabilizou o equilíbrio na balança de pagamentos. Os equívocos nas políticas agrárias foram reconhecidos pelo governo quando da realização do IV Congresso da FRELIMO, em que se criticou a marginalização do agricultor familiar que sempre desempenhou um papel importante na contribuição da produção para exportação e para o consumo interno;

A conjuntura internacional, marcado por um processo de mudanças globais provocadas pela crise do petróleo, pela imposição de políticas neoliberais principalmente em países que atravessavam a crise da dívida; e pela falência do projeto socialista, liderado pela Ex-URSS,que provocouimpactos significativos no financiamento para o projeto desenvolvimentista moçambicano.

Tabela 3: Anatomia de um colapso econômico 1973 - 1986 (Índice 1973 = 100)

\begin{tabular}{l|l|l}
1973 & 1980 & 1986
\end{tabular}

\begin{tabular}{lccc} 
Produção industrial & 100 & 77 & 35 \\
\hline Produção agrícola comercializada (volume) & & & \\
\hline Caju & 100 & 45 & 20 \\
\hline Algodão & 100 & 45 & 7 \\
\hline Milho & 100 & 54 & 18 \\
\hline Arroz & 100 & 79 & 55 \\
\hline Exportação de mercadorias & 100 & 122 & 34 \\
\hline Receitas de serviços & 100 & 79 & 55 \\
\hline Importação de mercadorias & 100 & 232 & 157 \\
\hline Despesas de serviços & 100 & 79 & 293 \\
\hline
\end{tabular}

Fonte: HERMELE (1990)

Em face desses constrangimentos, segundoHermele (1990), o país se encontrava no seu limite, pois os lucros obtidos nas transações internacionais eram absorvidos pelo serviço da dívida externa, significando que o país precisava encontrar novas soluções. Para o autor estas soluções passavam pela obtenção de fontes financeiras alternativas ou por acordos com os credores para a renegociação da dívida pendente. Todavia, a aplicação dessas soluções estava condicionada às mudanças significativas na política econômica, onde só com a introdução de políticas neoliberais seria possível garantir a aplicação da solução para a retomada do crescimento econômico do país.

a 
O partido sabia que a evolução econômica apresentaria tendência inversa a partir do momento que reformas econômicas e sociais fossem introduzidas. O IV Congresso da FRELIMO, realizado em 1983 demonstrou que a ideologia do partido precisava se ajustar ao novo cenário internacional e submeter-se aos ditames das agências multilaterais de financiamento. Marshall (1992?) argumenta que no mesmo ano de realização do congresso da FRELIMO o país já havia gasto todos os ganhos em moeda externa, não existindo divisas para gastar no pagamento de importações de vital importância, como os combustíveis, bens de consumo básico e medicamentos. Em 1984 o país se declara falido, "solicitando aos seus credores o reescalonamento das suas dívidas, adiantamento dos pagamentos dos empréstimos e juros de 1983-86 até 199198” (MARSHALL, 1992?, p.3). Marshall e Hermeledestacam que esse apoio foi condicionado à assinatura de um acordo com o Fundo Monetário Internacional e Banco Mundial. Hermele (1990) acrescenta que os EUA foram mais longe, ao exigirem que o país entrasse num acordo com a África do Sul, como forma de ganhar o apoio alimentar (que era fundamental, face ao agravamento da seca na região Sul do país), em créditos e donativos dos Estados Unidos ${ }^{33}$.

Como resultado das exigências dos principais credores internacionais ${ }^{34}$, o país assina um acordo de boa vizinhança e não agressão com a África do Su. É o acordo de Nkomati, assinado em março de 1984, mas em setembro do mesmo ano é assinadoo acordo de adesão às instituições do FMI e do BM. A assinatura desse acordo representou a derrota da ideologia política da FRELIMO (e do seu governo), que deixaria de apoiar o ANC (movimento que lutava contra o apartheid na África do Sul), como também crucificou as esperanças de condução de um projeto socialista. É importante destacar que não é o IV Congresso da FRELIMO que vem mudar o posicionamento do partido, apesar deste se apresentar como um marco, mas foi a partir dele que formalmente se pode apreender que o partido estava a passar por algumas reformas impostas de fora.

Sem muitas alternativas e, com uma economia em decadência, incapaz de satisfazer as necessidades internas, o país iniciou algumas reformas para poder aceder ao crédito das instituições ocidentais. O IV Congresso, que apesar de tentar demonstrar que era possível continuar com o projeto socialista, começava a mostrar as fraquezas da ideologia da FRELIMO e já se dirigiapara um conjunto de reformas que viriam a acontecer, mesmo antes da introdução do Programa de Reabilitação Econômica (PRE) introduzido no país em janeiro 1987. Depois da realização do IV Congresso e da aplicação de pré-reformas, as aldeias comunais e as cooperativas saíram da agenda do governo, ou seja, deixaram de fazer parte do projeto desenvolvimentista do governo.

${ }_{33}$ Para além dessa imposição, Hermele (1988) refere que o país também foi forçado a reconhecer que o Ocidente de Berlin fazia parte da República Federal da Alemanha.

${ }_{34}$ Cerca de dois terços da dívida de Moçambique pendente eram dos credores ocidentais (HERMELE, 1988) 


\section{CONSIDERAÇÕES FINAIS}

O domínio dos objetos e das ações que deveriam ocorrer no atual território nacional de Moçambique foi a estratégia usada, tanto pelo sistema colonial português como pela ideologia triunfante do partido FRELIMO. Organizar a ocupação do espaço de acordo com os seus interesses e com vista a satisfazer as suas necessidades passou a ser a característica marcante desses dois períodos da história moçambicana.

Ao se dominar o espaço do atual território moçambicano, constituído por vários territórios, com identidades e culturas diferentes, configurou-se o território uno, ou seja, o território de governança ${ }^{35}$. O território de governança, surgido do aniquilamento dos anteriores territórios, se orientou para satisfazer as necessidades do mercado internacional, principalmente do português, sul-africano e o britânico. Para responder a esses interesses o governo colonial construiu infraestruturas que visavam apenas responder aos interesses do capital sul-africano e britânico. Isso se materializou com a construção de portos, estradas de ferros e vias terrestres que estavam ao serviço desses países. Para além disso, o governo colonial destinou a região sul como reserva de mão de obra barata, principalmente para os seus parceiros regionais.

O restante das regiões foi (re)estruturado como área de produção agrícola, com algum investimento de capital estrangeiro. A região central do país foi reservada às grandes plantações, principalmente de chá, sisal, açúcar e coqueiros. Para o norte, região com ótimas condições para as culturas de algodão e caju foram criadas condições para que os agricultores familiares se dedicassem a essas culturas e a vendessem exclusivamente aos canais definidos pelo sistema colonial.

Para que este cenário de exploração da família ruralacontecesse era necessário que o agricultor familiar estivesse ligado à agricultura, mas a uma agricultura de subsistência em que o agricultor necessitasse trabalhar paravendersua mão de obra nas plantações, nas áreas de cultivo dos colonos, na cidade ou ainda nos países vizinhos. Essa necessidade de exploração, rentável para o sistema colonial, fez com que a família rural alterasse as formas de povoamento e a necessidade de um trabalho assalariado se tornou parte importante do seu processo de reprodução social. Assim, a família rural passou para um estágio em que ela se vê forçada a tornar-se assalariada ou semiproletária paramanter a sua reprodução social.

35 Veja FERNANDES, Bernardo Mançano. "Entrando nos territórios do Território". In: PAULINO, Eliane Tomiasi; FABRINI, João Edmilson. Campesinato e territórios em disputa. São Paulo: Expressão Popular, 2008. pp. 273-302 
O alcance da independência nacional colocou um fim ao sistema colonial implantado no território nacional. O mesmo não significou a concessão da independência dos territórios do território nacional, mas sim a sua consolidação. Para que o território uno se estabelecesse mais uma vez a organização do espaço teve que ser alterado, passando-se para o povoamento agrupado. Esta forma de povoamento que deslocou o espaço residencial do espaço produtivo estava associada às transformações nas relações sociais e de produção, marcadas pela introdução de formas coletivas de produção. Introduziu-se a socialização do campo como estratégia de desenvolvimento rural.

A socialização do campo seassentava na implementação de formas coletivas de vida e de produção. Essas formas, associadas à ideologia da FRELIMO (e do seu governo), tinham como missão destruir a mentalidade colonial e tradicional, isto é, a ideia era formar uma nova sociedade que não tivesse heranças dos sistemas antigos de administração e gestão dos territórios do território nacional, bem como do sistema colonial.

Nesse contexto, o que está em questão não é o território em si, mas o seu uso, como nos lembra Milton Santos, pois a forma como os atores, neste caso o Estado, vai organizar o sistema de objetos e de ações é fundamental para a materialização dos seus objetivos. A organização da população em povoamento agrupado, em que estava definido o espaço de residência, concentrando toda a população e o espaço de produção, contendo as machambas coletivas, permitia que as ações que se desenvolvessem nesse tipo de povoamento concorressem para a consolidação de uma nova sociedade, a sociedade socialista. Senão vejamos, por um lado, concentrando a população em determinados espaços, impedia-se o surgimento de famílias alargadas com os filhos casando e residindo próximo da família central;impedia-se que o homem tivesse várias mulheres e que se formasse uma espécie de clã, ou de um espaço sob o domínio do chefe da família;impedia-se o surgimento e consolidação dos regulados, considerados antigos senhores feudais. Por outro lado, ao se concentrarem as machambas, formando as cooperativas de produção, onde todos deveriam trabalhar e consumirem coletivamente os resultados da produção, deslocava-se o centro da acumulação, do individual para o coletivo. Lutava-se contra a formação do pequeno burguês e da mentalidade individualista.

A transformação na forma de organização e ocupação do espaço também visava fornecer os serviços sociais básicos à população, melhorando a condição de vida, depois de séculos de privação. Sendo assim, o Estado desempenharia um papel importante, pois este concentraria a população, facilitando o fornecimento dos serviços sociais a população, ao mesmo tempo em que forjava uma sociedade alicerçada na aliança entre os camponeses e os operários. Para que essa sociedade fosse construída, era preciso que se eliminasse 
o surgimento e aconsolidação da sociedade burguesa, herança da colonização, como também a sociedade tradicional, fruto de um processo histórico-cultural materializada nos regulados. A luta contra a sociedade tradicional tinha como objetivo impedir que se consolidassem a autonomia dos territórios do território nacional

Quando se produz um território, que é, muitas vezes, resultado das estratégias dos atores dominantes, que impõem as suas vontades no território, há sempre processos de resistência, quer eles sejam silenciosos ou silenciados. A socialização do campo encontrou resistências silenciosas e silenciadas, principalmente ao nível dos agricultores familiares que sedeparavam diante dessa nova forma de uso do território comoum obstáculo às suas pretensões. As resistências silenciosas são caracterizadas pela (i) "aderência" dos agricultores às aldeias comunais, mas mantendo sempre a sua machamba individual nas antigas áreas de assentamento; (ii) dedicação maior às machambas individuais em detrimento da coletiva; (iii) participação nas cooperativas apenas como uma forma de aceder aos apoios fornecidos pelo Estado, que depois eram canalizados para a concretização de objetivos particulares; (iv) trabalho nas cooperativas apenas quando o apoio estatal chegava, caso contrário a atividade só iniciaria depois da chegada do apoio estatal; (v) recorrência ao trabalho assalariado sempre que a oportunidade surgisse. Em relação às resistências silenciadas, foram todas aquelas resistências das quais não foram admitidas como tal e, que em alguns casos, lhesforam atribuídas outras motivações.

O insucesso da socialização do campo também pode ser atribuído a causas externas. São os casos do impacto da política sul-africana de não usar mais o porto e as estradas de ferro de Maputo; o apoio sul-africano ao movimento de desestabilização nacional, levado a cabo pela RENAMO; a incapacidade da Ex-URSS em apoiar o projeto desenvolvimentista moçambicano; a crise do petróleo que impactou severamente na economia nacional; e a crise da dívida. Associado a isso, incluem-se o fraco desempenho da produção agrícola interna, as condições climáticas adversas e o avanço da guerra de desestabilização que tinha seu principal foco nas infraestruturas sociais e econômicas e nas aldeias comunais.

O sonho da construção de uma sociedade socialista começa a desmoronar ainda nos inícios da década de 80 e, o IV Congresso da FRELIMO vem sutilmente demonstrar que não havia mais condições para levar o sonho adiante. As negociações com as instituições de Brettons Woods já estavam em andamento e um acordo com o governo de minoria branca da África do Sul foi firmado, sob a bandeira de acordo de "boa vizinhança”. Os caminhos estavam criados para a entrada de políticas neoliberais e, com ela a acumulação por espoliação. 
Da experiência da socialização do campo que lições podem ser tiradas para a atual fase em que o país vem se destacando como um país rico em recursos naturais e, cuja atividade exploratóriavem promovendo processos de des-reterritorialização, materializados nos reassentamentos? Até o momento, estudos realizados por vários pesquisadores moçambicanos, incluindo os autores deste artigo, vêm demonstrando que esses processos são carregados de procedimentos e ações que deterioram a qualidade de vida das famílias afetadas. Que diferenças existem entre a socialização do campo e os processos de reassentamento realizados atualmente no país? É sobre essas e outras questões que pretendemos refletir em próximos artigos para compreendermos que mudanças ocorreramao nível da família rural desde a introdução das reformas econômicas em 1987 e, se a aposta nos grandes projetos da indústria extrativa está promovendo o desenvolvimento da família rural, principalmente daquelas afetadas com a sua implementação.

\section{REFERÊNCIAS}

1. ALBERTS, Tom. COLLECTIVIZED AGRICULTURE: THE CASE OF MOZAMBIQUE. MAPUTO. AUGUST 1983.

2. ALMEIDA SERRA, António M. de. Política agrária e desenvolvimento econômico na República Popular de Moçambique, 1975-85. 1991. Tese de Doutorado. Instituto Superior de Economia e Gestão, Universidade Técnica de Lisboa. Lisboa, 1991.

3. ARAÚJO, Manuel G. M. de. O sistema das aldeias comunais em Moçambique: transformações na organização do espaço residencial e produtivo. 1989. Tese de doutorado. Faculdade de Letras, Universidade de Lisboa. Lisboa, 1989.

4. BRAUN, Gerard. War and economic reform in Mozambique.Freiburg, Dez. 1988.

5. CASTEL-BRANCO, Carlos N. A questão agrária em Moçambique. Centro de Estudos Africanos: workshop Moçambique no pós-guerra: Diálogos e perspectivas. Maputo.

6. CASTEL-BRANCO, Carlos N. Trabalho assalariado e pequena produção mercantil na estratégia de socialização do campo. Maputo: Centro de Estudos Africanos/Departamento de Economia do Comité Central do Partido Frelimo, 1984

7. CENTRO DE ESTUDOS AFRICANOS. As famílias camponesas da Angónia no processo de socialização do campo. Maputo: Centro de Estudos Africanos/Universidade Eduardo Mondlane, 1983.

8. CENTRO DE ESTUDOS AFRICANOS. Problemas de transformação rural na província de Gaza: um estudo sobre a articulação entre aldeias comunais selecionadas, cooperativas agrícolas e a unidade de produção do baixo Limpopo (unpbl). Maputo: Centro de Estudos Africanos/Universidade Eduardo Mondlane, 1979. 
9. CENTRE FOR DEVELOPMENT RESEARCH. Rural development in Mozambique. Copenhagen: CDR Project Proposal D 78.6, march, 1978.

10. HALKES, Jam; OPPEWAL, Jolke. Moçambique, socialismo e solidariedade. Amsterdão: Edição da Fundação Eduardo Mondlane, 1989.

11. HEDGES, David. História de Moçambique: Moçambique no auge do colonialismo, 1930-1961. Volume 2. Maputo: Livraria Universitária Eduardo Mondlane, 2ª edição, 1999.

12. HERMELE, Kenneth. Moçambique numa encruzilhada: economia e política na era de ajustamento estrutural. Bergen: CHR. Michelsen Institute. Departamentos Social Science and Development, 1990.

13. HERMELE, Kenneth. War and stabilization: a mid-tern review of Mozambique's Economic Rehabilitation Programme (PRE) with implications for Swedish development assistance. Country ReportMozambique, october 1988.

14. HERMELE, Kenneth. Diferenciação rural e estratégia de desenvolvimento: apontamentos sobre Moçambique no período de transição 1974-1977. Rascunho.Estocolmo, fevereiro de 1987.

15. HERMELE, Kenneth. Reorganization and interdependence: the agricultural set-up in Chokwe, Gaza province. Maputo, march 1986.

16. MACKINTOSH, Maureen; WUYTS, Marc. "Accumulation, socialism services and socialist transition in the third world: reflections on decentralized planning based on Mozambican experience”. In: DPP Working Paper, no. 9, United Kingdon: The Open University, 1987.

17. MARSHALL, Judith. Guerra, dívida e ajustamento estrutural em Moçambique: o impacto social. Ottawa: The North-South Institute, 1992?

18. MARSHALL, Judith.Structural Adjustment and social policy in Mozambique.In: ReviewofAfricanPoliticalEconomy. no. 47, Spring 1990.

19. MATOS, Elmer A. C. de; MEDEIROS, Rosa M. V. “Acesso a terra e exploração mineira em Moçambique: que implicações para as comunidades locais". In: Campo e Território: revista de geografia agrária, v.9, n.17, p. 559-621, abri., 2014

20. MOSCA, João. Economia de Moçambique: século XX. Lisboa: Instituto PIAGET, 2005.

21. NEGRÃO, José. “A terra e a economia da família rural no Delta do Zambéze”. In: Seminário da Comissão de Terras, Maputo: Núcleo de Estudos Terra \& Desenvolvimento, 1995.

22. O'LAUGHLIN, Bridgest. "Past and present options: land, reform in Mozambique".In: Review of African Poliical Economy, no. 63, p. 99-106. 1995.

23. PITCHER, A. Anne. "Sobreviver à transição: o legado das antigas empresas coloniais em Moçambique”. In: Análise Social, vol. XXVIII (168). p.793-820, 2003

24. VIEIRA, Sérgio. “O homem novo é um processo”. In: Movimento das ideias. Maputo, [1979?]. Artigo recebido em 29 de maio de 2015.

Artigo aceito em 15 de junho de 2015. 